\title{
SOSIALISASI PEMANFAATAN PELEPAH PISANG SEBAGAI MATERIAL DINDING KEDAP SUARA DI DESA KEBON KOLIM KABUPATEN MUSI RAWAS
}

\author{
Ovilia Putri Utami Gumay ${ }^{1}$, Fitria Lestari ${ }^{2}$, Merti Triyanti ${ }^{3}$ \\ ${ }^{1)}$ Program Studi Pendidikan Fisika, Jurusan Matematika dan IPA, STKIP PGRI Lubuklinggau \\ ${ }^{2,3)}$ Program Studi Pendidikan Biologi, Jurusan Matematika dan IPA, STKIP PGRI Lubuklinggau \\ e-mail: zhoulia127@gmail.com
}

\begin{abstract}
Abstrak
Kebisingan merupakan salah satu bentuk polusi suara yang dapat membuat lingkungan terasa tidak nyaman. Umumnya untuk meredam kebisingan, masyarakat menggunakan panel akustik yang dipasang pada dinding pemisah (partisi) dan plafon. Namun, penggunaan panel akustik memerlukan biaya yang tidak murah. Oleh karena itu, salah satu peredam suara yang murah dan ramah lingkungan adalah pelepah pisang yang sangat jarang dimanfaatkan di kalangan masyarakat Desa Kebon Kolim. Metode pelaksanaan kegiatan ini dimulai dari sosialisasi dan pemberian pengetahuan tentang 1) Jenis bahan material dinding kedap suara 2) pola anyaman material dinding kedap suara 3) tingkat keawetan bahan terhadap pengaruh iklim. Hasil dari kegiatan ini dapat disimpulkan bahwa pelepah pisang berpotensi sebagai material dinding kedap suara yang dapat dibuat dengan mudah oleh masyarakat.
\end{abstract}

Kata Kunci: Kedap Suara, Pelepah Pisang

\begin{abstract}
Noise is a form of noise pollution that can make the environment feel uncomfortable. Generally, to reduce noise, people use acoustic panels that are mounted on a dividing wall (partition) and ceiling. However, the use of acoustic panels is not cheap. Therefore, one of the cheap and environmentally friendly sound absorbers is banana stalk which is rarely used by the community Desa Kebon Kolim. The method of implementing this activity starts from the socialization and provision of knowledge about 1) the type of soundproof wall material 2) the woven pattern of the soundproof wall material 3) the level of durability of the material against the effects of climate. The results of this activity can be concluded that banana leaves have the potential as a soundproof wall material that can be made easily by the community.
\end{abstract}

Keywords: Soundproof, Banana Stems

\section{PENDAHULUAN}

Kebisingan adalah bunyi yang tidak dikehendaki karena tidak sesuai dengan konteks ruang dan waktu sehingga dapat menimbulkan gangguan terhadap kenyamanan dan kesehatan manusia (Sasongko dkk., 2000). Polusi suara yang berasal dari kebisingan merupakan permasalahan klasik di Indonesia. Kebisingan juga dapat didefinisikan sebagai berikut:1. Menurut Keputusan Menteri Tenaga Kerja No.KEP-51/MEN/1999 menyebutkan bahwa kebisingan adalah semua suara yang tidak dikehendaki yang bersumber dari alat-alat proses produksi dan atau alat-alat kerja yang berada pada titik tertentu dapat menimbulkan gangguan pendengaran; dan 2. Sedangkan menurut Peraturan Menteri Kesehatan R.I. No.718/MENKES/PER/XI/1987 tentang kebisingan yang berhubungan dengan kesehatan bahwa kebisingan adalah terjadinya bunyi yang tidak dikehendaki sehingga mengganggu dan membahayakan kesehatan.

Kebisingan dapat direduksi dengan menggunakan material yang dapat meredam dan menyerap bunyi. Material penyerap bunyi mempunyai peranan penting dalam akustik ruangan, perancangan studio rekaman, ruang perkantoran, sekolah dan ruangan-ruangan yang lain untuk mengurangi kebisingan. Untuk mereduksi kebisingan pada suatu ruangan biasanya panel akustik di pasang pada dinding pemisah (partisi) dan plafon (Thamrin dkk., 2013). 
Semakin mahalnya harga barang termasuk peredam suara, maka masyarakat berupaya untuk mencari alternatif lain dengan mulai memanfaatkan bahan yang berasal dari alam yang mudah didapatkan dan lebih murah karena memanfaatkan serat alam sebagai bahan peredam suara.Salah satu contoh dengan memanfaatkan serat alam yaitu dari pelepah pisang.

Tanaman ini mudah didapatkan, memiliki beberapa manfaat, dan harga relatif murah. Pohon pisang sering dijumpai di lingkungan sekitar kita. Pohon pisang sering dijumpai di setiap pekarangan rumah, di pinggir jalan serta di sawah-sawah di pedesaan. Pohon pisang di Indonesia menjadi salah satu komoditas yang dapat dimanfaatkan. Pisang dikonsumsi oleh semua kalangan masyarakat. Pisang dijual dengan berbagai tingkatan mutu dan harga yang sangat bervariasi satu sama lain. Indonesia memiliki lebih dari 230 jenis pisang. Dari beberapa jenis pisang di Indonesia hanya beberapa jenis pisang yang dijual di pasaran, dikonsumsi oleh masyarakat dan mudah untuk mendapatkannya, diantaranya adalah: Pisang Barangan, Raja, Raja Sereh (RajaSusu), Raja Uli, Raja Jambe, Raja Molo, Raja Kul, Raja Tahun, Raja Bulu, Kepok, Tanduk, Mas, Ambon Lumut, Ambon Kuning, Nangka, Kapas, Kidang, Lampung, dan pisang Tongkat Langit. Pohon pisang memiliki banyak keistimewaan dibanding jenis tanaman yang lain. Penelitian terdahulu menyebutkan bahwa pelepah pisang Kepok bisa menjadi alternatif bahan dinding kedap suara. Pisang Raja Susu dipilih karena jumlahnya melimpah dan harganya lebih murah dibandingkan dengan pisang kepok.

Berdasarkan hasil observasi di lapangan, selama ini masyarakat hanya menggunakan pelepah pisang sebagai bahan pupuk. Persoalan selanjutnya adalah belum memiliki pengetahuan untuk mengolah pelepah pisang sebagai material kedap suara.

\section{METODE}

\section{a. Pelaksanaan Program}

Pelaksanaan sosialisasi ini direncanakan pada bulan Maret 2020 di Desa Kebon Kolim Kabupaten Musi Rawas. Peserta sosialisasi terdiri dari masyarakat yang berjumlah 30 orang dan akan dibimbing oleh 2 mahasiswa pendamping agar sosialisasi berjalan dengan efektif. Kegiatan ini bekerjasama dengan kepala desa Kebon Kolim Kabupaten Musi Rawas sebagai jembatan langsung agar target luaran dapat tercapai secara maksimal.

Adapun pelaksanaan program terdiri dari:

\section{Tahap Sosialisasi}

Pada tahap ini, akan diadakan sosialisasi tentang pemanfaatan pelepah pisang sebagai material dinding kedap suara.

\section{Tahap Pemberian Pengetahuan}

Pemberian pengetahuan dasar masyarakat mengenai: 1) Jenis bahan material dinding kedap suara 2) pola anyaman material dinding kedap suara 3) tingkat keawetan bahan terhadap pengaruh iklim

Kegiatan ini melibatkan narasumber berasal dari dosen-dosen dengan keahlian dibidang masing-masing sehingga dapat saling melengkapi dan berbagi pikiran dan pengetahuan.

\section{b. Indikator Keberhasilan Program}

Indikator keberhasilan program yaitu meningkatnya pengetahuan mengenai pelepah pisang dan cara mengolahnya menjadi material dinding kedap suara.

\section{HASIL DAN PEMBAHASAN}

\section{A. Hasil Pelaksanaan Kegiatan}

Kegiatan pengabdian Kepada Masyarakat adalah sebuah tugas dan kewajiban seorang dosen untuk menjadi masyarakat memiliki wawasan pengetahuan. Semoga dengan kegiatan "Sosialisasi pemanfaatan pelepah pisang sebagai material dinding kedap suara di Desa Kebon Kolim Kabupaten Musi Rawas", dapat memberikan pengetahuan dan informasi tentang memanfaatkan pelepah pisang sebagai material dinding kedap suara. Kegiatan pelaksanaan PPM dilaksanakan pada tanggal 6-8 Maret 2020 dengan peserta sebanyak 30 orang secara tatap muka. 
Pengabdian ini dilaksanakan oleh 3 orang dosen dan 2 orang mahasiswa. Tiga orang dosen memberikan materi tentang: 1) Mengetahui Jenis bahan material dinding kedap suara 2) Mengetahui pola anyaman material dinding kedap suara 3) Mengetahui tingkat keawetan bahan terhadap pengaruh iklim

\section{B. Pembahasan Pelaksanaan Kegiatan}

Hasil kegiatan PPM berjudul "Sosialisasi pemanfaatan pelepah pisang sebagai material dinding kedap suara di Desa Kebon Kolim Kabupaten Musi Rawas" secara garis besar mencakup komponen, yaitu: 1) memberikan pengetahuan tentang cara memanfaatkan pelepah pisang sebagai material dinding kedap suara dan 2) ketercapaian pemahaman peserta mengenai cara membuat material dinding kedap suara dari pelepah pisang.

Target jumlah peserta pada kegiatan ini adalah masyarakat yang berjumlah 30 orang dalam pelaksanaannya. Adapun materi yang disampaikan, yaitu1) Mengetahui Jenis bahan material dinding kedap suara 2) Mengetahui pola anyaman material dinding kedap suara 3) Mengetahui tingkat keawetan bahan terhadap pengaruh iklim. Materi yang direncanakan tersebut telah dilaksanakan secara keseluruhan, sehingga materi tuntas. Pada kegiatan pemberian materi, tim PKM melakukan komunikasi secara aktif kepada peserta sehingga respon yang diberikan baik. Setelah materi disampaikan, kegiatan selanjutnya adalah demonstrasi secara langsung cara mengolah pelepah pisang menjadi material dinding kedap suara. Adapun tahapannya, yaitu: membuat beberapa jenis anyaman dari pelepah pisang yang sudah dikeringkan. Pelepah pisang yang sudah dipilih dikeringkan kemudian dibuat anyaman. Anyaman tersebutkemudian diberi pelapis finishing triplek, agar bisa digunakan sebagai partisi dinding. Kegiatan ini dilakukan di rumah warga setempat, yaitu dengan membawa bahan uji yang digunakan yaitu pelepah pisang kepok.

Bagian pelepah pisang yang terdiri dari bagian luar, tengah dan dalam memiliki karakteristik yang berbeda. Berdasarkan pengamatan, pelepah pisang yang bisa digunakan dalam kegiatan ini adalah pada bagian tengah batang. Pelepah pisang pada bagian luar dan paling dalam dari batang pisang tidak bisa digunakan. Hal ini terjadi karena pada saat proses pengeringan, kadar air pada pelepah pisang tersebut berkurang, sehingga tingkat ketebalan dan rongganya menjadi tipis. Hal ini kurang memenuhi persyaratan ketebalan untuk digunakan sebagai dinding kedap suara. Pelepah pisang pada bagian tengah memiliki daging yang cukup tebal, setelah dikeringkan rongga dan poripori pada pelepah pisang tersebut masih memiliki ketebalan yang cukup. Untuk mengetahui kemampuan daya serap yang paling optimum dilakukan dengan jenis variasi dan kombinasi susunanan nyaman yang berbeda. Hal ini juga berpengaruh terhadap luasan dinding kedap suara yang dihasilkan. Pelepah pisang yang sudah dikeringkan, memiliki tekstur yang berserabut dan berpori. Hal ini sebenarnya bisa juga menjadi alternatif bahan dasar material dinding kedap suara.

Elemen penyerap bunyi yang berpori mempunyai karakteristik penyerapan lebih efisien, selain itu ketebalan dan jarak lapisan dinding juga menentukan optimalisasi tingkat peredaman terhadap bunyi.

Perubahan musim sangat berpengaruh terhadap perubahan suhu dan kelembaban. Kelembaban menjadi tinggi pada musim hujan dan suhu menjadi tinggi pada musim kemarau. Suhu dan kelembaban sangat berpengaruh terhadap keawetan material dinding atau partisi dalam ruangan. Material yang tidak tahan pada suhu dan kelembaban yang tinggi biasanya akan mengalami perubahan bentuk. Perubahan yang terjadi diantaranya adalah rapuh, retak-retak, berjamur dan rusak. Kerusakan yang terjadi akan mempengaruhi kekuatan material.Hasil kegiatan ini menunjukkan bahwa partisi yang terbuat dari bahan pelepah pisang cocok untuk digunakan pada kondisi lembap. Salah satu ciri daerah yang beriklim tropis adalah kelembaban yang tinggi terutama pada saat musim hujan. Bahan ini tahan terhadap kelembaban tinggi dalam ruang. Partisi ini menjadi salah satu alternatif bahan dinding kedap suara pada interior rumah tinggal yang cocok digunakan untuk daerah yang memiliki iklim tropis.

\section{SIMPULAN}

Beradasarkan kegiatan yang telah dilakukan dapat disimpulkan bahwa pelepah pisang berpotensi sebagai material dinding yang kedap suara yang murah dan ramah lingkungan. 


\section{SARAN}

Adapun saran yang dapat diberikan bahwa pada saar melakukan proses pengeringan baiknya lebih lama dan benar-benar kering agar mendapatkan hasil yang baik.

\section{UCAPAN TERIMA KASIH}

Ucapan terimakasih kami sampaikan kepada STKIP PGRI Lubuklinggau yang telah memberikan bantuan untuk terlaksananya kegiatan pengabdian pada masyarakat ini.

\section{DAFTAR PUSTAKA}

Khuriati, Aini, dkk. (2006). Disain Peredam Suara Berbahan Dasar Sabut Kelapa dan Pengukuran Koefisien Penyerapan Bunyinya. Berkala Fisika, Vol.9 No.11, 15-25, ISSN : 1410 -9662 Suharyani, dkk. (2014). Pemanfaataan Limbah Pelepah Pisang Raja Susu untuk BahanMaterial Dinding Kedap Suara. Simposium Nasional RAPI XIII -2014 FT UMS ISSN : 1412-9612

Suharyani, dkk. (2015). Limbah Pelepah Pisang Raja Susu Sebagai Alternatif Bahan Dinding Kedap Suara. Jurnal Sinektika Program Studi Arsitektur FTUMS 